\title{
Razlike u otvorenosti i dijeljenju znanstvenih radova na Sveučilištu u Rijeci*
}

\section{Differences in Openness and Sharing of Scientific Papers at the University of Rijeka*}

\section{Iva Vrkić ${ }^{1}$, Ivana Hebrang Grgić ${ }^{2}$ Jadranka Stojanovski ${ }^{3}$, Ksenija Baždarićc}

${ }^{1}$ Sveučilište u Zagrebu, Prirodoslovno-matematički fakultet, Zagreb, Hrvatska / University of Zagreb, Faculty of Science, Zagreb, Croatia; http://orcid.org/0000-0002-3221-5204

ivavrkic@gfz.hr

${ }^{2}$ Sveučilište u Zagrebu, Filozofski fakultet, Zagreb, Hrvatska / University of Zagreb, Faculty of Humanities and Social Sciences, Zagreb, Croatia; http://orcid.org/0000-0001-6709-9939

ivana.grgic@ffzg.hr

${ }^{3}$ Sveučilište u Zadru, Zadar; Institut Ruđer Bošković, Zagreb, Hrvatska / University of Zadar, Zadar; The Ruđer Bošković Institute, Zagreb, Croatia; http://orcid.org/0000-0001-7399-522X

Jadranka.Stojanovski@irb.hr

${ }^{4}$ Sveučilište u Rijeci; Medicinski fakultet; Rijeka; Hrvatska / University of Rijeka; Faculty of Medicine; Rijeka; Croatia; http:// orcid.org/0000-0002-2977-3686

ksenija.bazdaric@uniri.hr

\section{Informacije o članku / Article Info}

Primljen / Received 17. 3. 2020.

Prihvaćen / Accepted 29. 5. 2020.

Dostupan online / Available online: 15. 12. 2020.

\section{Ključne riječi / Keywords:}

ArXiv, Crosbi, Dabar, društvene mreže, institucijski repozitorij, otvoreni pristup, ResearchGate, samoarhiviranje, SCImago Journal Rank, tematski repozitorij ArXiv, CROSBI, Dabar, institutional repository, open access, ResearchGate, SClmago Journal Rank, self-archiving, social networks, subjectbased repository

\section{Sažetak / Abstract}

Cilj: utvrditi razlike u otvorenosti i dijeljenju znanstvenih radova na Sveučilištu u Rijeci. Metode: Analizirani su znanstveni radovi autora Sveučilišta u Rijeci iz Hrvatske znanstvene bibliografije (CROSBI) u 4 područja (2017.-2019.) na uzorku od 210 radova. Kao metrički pokazatelj kvalitete časopisa korišteni su kvartili SciMago Journal Rank (SJR). Provjerena je prisutnost cjelovitog teksta $u$ otvorenom pristupu u 3 vrste repozitorija (Repozitorij UNIRI - Dabar, ArXiv, Crosbi) i na društvenoj akademskoj mreži ResearchGate. Istraženo je postojanje razlika u stupnju sklonosti samoarhiviranju i dijeljenju radova s obzirom na područje znanosti.

Rezultati: Znanstvenici iz područja prirodnih znanosti ( $N=55,78,6 \%)$ i biomedicine i zdravstva $(\mathrm{N}=49,70 \%)$ značajno više $(\mathrm{P}<0,001)$ objavljuju u časopisima u Q1 i Q2 kvartilama. Autori iz područja društvenih i humanističkih znanosti više objavljuju u Q3 i Q4 te časopisima izvan baze podataka Scopus ( $N=57,81,4 \%)$. Udio radova u otvorenom pristupu ( $N=107$, $51 \%)$ približno je jednak udjelu u zatvorenom pristupu ( $N=103,49 \%)(P=0,7825)$. Za samoarhiviranje i dijeljenje radova znanstvenici su koristili platformu ResearchGate ( $\mathrm{N}=77)$, ArXiv $(\mathrm{N}=32)$, Repozitorij UNIRI ( $\mathrm{N}=15)$ i Crosbi $(\mathrm{N}=9)$. Od svih područja znanosti, analiziramo li radove $s$ visokim stupnjem sklonosti samoarhiviranju i dijeljenju, prednjače autori iz područja prirodnih znanosti $(\mathrm{N}=21,60 \%)$.

Zaključak: Najveći stupanj sklonosti samoarhiviranju i dijeljenju rada pokazuju znanstvenici iz prirodnih znanosti. Nije uočena povezanost između SJR kvartila časopisa i sklonosti autora da samoarhivira ili podijeli svoj rad na otvorenoj platformi.

Aim: to determine differences in openness and sharing of scientific papers.

Methods: We have analysed scientific papers from the Croatian Scientific Bibliography (CROSBI) from University of Rijeka (Croatia) in 4 fields (2017-2019) on a sample of 210 papers. The SciMago Journal Rank (SJR) quartiles were used as a metric. We have checked the presence of the full text in open access in 3 types of repositories (Repository UNIRI-Dabar, ArXiv, CROSBI) and on social academic network ResearchGate. Tendency of self-archiving and sharing with regard to the field of science was investigated.

Results: Scientists in the field of natural sciences ( $N=55,78.6 \%)$, and biomedicine and health $(\mathrm{N}=49,70 \%)$ publish more $(\mathrm{P}<0.001)$ in Q1 and Q2 journals. Social sciences and humanities authors publish mostly in Q3 and Q4 journals and in journals not indexed in the Scopus database $(\mathrm{N}=57,81.4 \%)$. The proportion of open access papers $(\mathrm{N}=107,51 \%)$ is equal to closed papers $(N=103,49 \%)(P=0,7825)$. Scientists used ResearchGate platform $(\mathrm{N}=77)$, ArXiv ( $\mathrm{N}=32)$, UNIRI Repository $(\mathrm{N}=15)$ and CROSBI $(\mathrm{N}=9)$ for the self-archiving and sharing of papers. High degree of tendency for self-archiving and sharing was observed in the field of natural sciences ( $N=21,60 \%)$.

Conclusion: The highest degree of tendency for self-archiving and sharing is shown by natural scientists. There was no correlation between SJR quartile and the author's tendency to self-archive or share his work on an open platform.

\footnotetext{
" Istraživanje je financirano projektom Poznavanje, stavovi i korištenje alata otvorene znanosti u biomedicini (uniri-biomed-18-99) Sveučilišta u Rijeci. / The research was funded by the project Knowledge, attitudes and use of open science tools in biomedicine (uniri-biomed-18-99) of the University of Rijeka.
} 


\section{Uvod}

Otvorena znanost je pristup znanosti koji označava promjenu sustava kroz otvorene i suradničke načine komuniciranja, stvaranja i dijeljenja znanja, resursa, rezultata i podataka, u što ranijoj fazi istraživanja. Koncept otvorene znanosti uključuje i nove načine financiranja, evaluiranja i nagrađivanja istraživača te ima za cilj osigurati reproducibilnost, potaknuti interdisciplinarnost i povećati samu kvalitetu, utjecaj, učinkovitost znanosti i pokazati osjetljivost na potrebe društva (European Commission - Open Science Factsheet 2019, 1).

Praktične manifestacije koncepta otvorene znanosti različito se raščlanjuju. Prema poimanju Europske komisije, pojam otvorene znanosti veže se uz nekoliko domena: otvorene istraživačke podatke, otvorene komunikacijske infrastrukture, nove metričke pokazatelje znanstvene kvalitete i utjecaja, otvoreni pristup recenziranim znanstvenim publikacijama, brigu za znanstvenoistraživačku čestitost i uključivanje javnosti u znanstveni proces (European Commission - Open Science Factsheet 2019, 1).

Ayris i Ignat (2018, 2-3) su detektirali 11 elemenata otvorene znanosti koji se mogu primijeniti u svim fazama istraživačkog procesa - konceptualizaciji, prikupljanju podataka, analizi, recenziji i objavi istraživanja. U tom su smislu izdvojili sljedeće komponente: otvoreni pristup publikacijama (engl. Open Access ili $O A$ ), otvoreni kôd (engl. Open source code), nerecenzirane inačice radova u otvorenim repozitorijima (engl. Pre-print), otvoreni recenzijski postupak (engl. Open peer review), alternativni sustavi vrednovanja (engl. Alternative reputation systems), kolaborativne bibliografije (engl. Collaborative bibliographies), znanstveni blogovi, otvorene istraživačke bilješke (engl. Open annotation), otvoreni istraživački podaci (engl. Open data), otvoreni dijagrami procesa (engl. Open lab books / workflows) i uključivanje javnosti u znanstveni proces (engl. Citizen science).

Pristupi i taksonomije elemenata otvorene znanosti različito se interpretiraju. U literaturi se često citira vrlo fragmentirana taksonomija sastavljena u sklopu FOSTER projekta Europske komisije (Pontica et al. 2015, 3), iako se neki autori ne slažu s hijerarhijskim odnosima unutar nje. Pa tako Tennant i sur. $(2020,9)$ i Watson (2015) smatraju da je otvorena znanost zapravo proizašla iz pokreta softvera otvorenog kôda (engl. Free and open source software) te da otvoreni kôd nije pomoćni element u hijerarhiji, kako to predlaže FOSTER. I Dizdar $(2019,31)$ zaključuje da je računalna infrastruktura iznjedrila

\section{Introduction}

Open science is an approach to science that signify changes of the system through open and collaborative ways of communicating, creating and sharing knowledge, resources, results and data, at the earliest possible stage of research. The concept of open science includes new ways of funding, evaluating and rewarding researchers and aims to ensure reproducibility, encourage interdisciplinarity and increase the quality, impact, effectiveness of science and demonstrate sensitivity to the needs of society (European Commission - Open Science Factsheet 2019, 1).

The practical manifestations of the concept of open science are divided differently. According to the $E u$ ropean Commission, the concept of open science is related to several fields: open research data, open communication infrastructures, new metrics of scientific quality and impact, open access to peer-reviewed scientific publications, concern for scientific integrity and public involvement in the scientific process (European Commission - Open Science Factsheet 2019, 1).

Ayris and Ignat (2018, 2-3) detected 11 elements of open science that can be applied at all stages of the research process - conceptualization, data collection, analysis, review, and research publishing. In this regard, they determined the following components: Open Access or OA, Open source code, unreviewed versions of papers in open repositories (Pre-print), Open peer review, Alternative reputation systems, Collaborative bibliographies, scientific blogs, Open annotation, open research data (Open data), open process diagrams (Open lab books / workflows) and public involvement in the scientific process (Citizen science).

Approaches and taxonomies of the elements of open science are interpreted differently. The literature often cites a very fragmented taxonomy compiled as part of the European Commission's FOSTER project (Pontica et al. 2015, 3), although some authors disagree with the hierarchical relationships within it. That is why Tennant, et al. $(2020,9)$ and Watson (2015) argue that open science actually originated from the Free and open source software movement, and that open source is not an auxiliary element in the hierarchy, as suggested by FOSTER. Dizdar $(2019,31)$ also concludes that computer infrastructure has originated open science, i.e. the conditions for the current transfer of information to a large number of simultaneous users. Open access $(O A)$ to scientific information is an important element of 
otvorenu znanost, tj. uvjete za trenutni prijenos informacija velikom broju istovremenih korisnika. Otvoreni pristup znanstvenim informacijama (engl. Open Access, $O A$ ) važan je element pokreta otvorene znanosti i može se proglasiti da je condicio sine qua non.

Prva inicijativa usmjerena zagovaranju otvorenog pristupa nastala je u Budimpešti 2002. godine (engl. Budapest Open Access Initiative, BOAI) i tada je definirano da se otvorenim pristupom smatra slobodna dostupnost znanstvene literature na javnoj mreži, dopuštajući svim korisnicima da bez financijskih, pravnih ili tehničkih prepreka čitaju, preuzimaju, kopiraju, distribuiraju, ispisuju, pretražuju ili povezuju s cjelovitim tekstovima tih članaka, indeksiraju ili ih koriste u bilo koje druge zakonite svrhe, a sve uz osiguravanje autorima kontrole nad integritetom djela i pravo na odgovarajuće priznavanje i citiranje. Predlažu se dvije strategije za ostvarenje otvorenog pristupa: samoarhiviranje (engl. Self-Arhiving) i objavljivanje u časopisima s otvorenim pristupom (engl. Open-Access Journals) (Budapest Open Access Initiative 2002).

Hrvatska deklaracija o otvorenom pristupu (2012, 2), oslanjajući se na prethodne inicijative, ${ }^{1}$ definirala je otvoreni pristup kao "slobodan", besplatan i neometan pristup digitalnim znanstvenim informacijama koji omogućava čitanje, pohranjivanje, distribuciju, pretraživanje, dohvaćanje, indeksiranje i/ ili drugo zakonito korištenje".

Kako su se znanstveni radovi objavljeni u časopisima nametnuli kao najvažniji kanal izvještavanja o znanstvenim postignućima i spoznajama, otvoreni pristup najčešće se odnosi na slobodan pristup radovima objavljenima u časopisima. Kada govori o otvorenom pristupu znanstvenim informacijama, i Europska komisija se osvrće najviše na časopise, razlikujući dvije kategorije ovog koncepta: recenzirane znanstvene publikacije (primarno znanstvene članke objavljene u znanstvenim časopisima) i istraživačke podatke koji upotpunjuju izvještavanje o rezultatima znanstvenih istraživanja u časopisima ili djeluju samostalno unutar istraživačkog okoliša putem cjelovitih i strukturiranih setova istraživač-

\footnotetext{
Budimpeštanska inicijativa o otvorenom pristupu (2002.), Berlinska deklaracija o otvorenom pristupu (2003.), Budimpeštanske deklaracije o pravu na pristup informacijama (2008.), Izjava o otvorenom pristupu (IFLA, 2011.), Načela i preporuke za pristup istraživačkim podacima nastalim u okviru istraživanja financiranih iz javnih izvora (OECD, 2007.), Preporuke o pristupu i očuvanju znanstvenih informacija (2012.), Zaključak Vijeća Europske unije o znanstvenim informacijama u digitalnom dobu: pristup, diseminacija i čuvanje (2007.)

2 Trajno oslobođen od bilo kakvih ograničenja i postavljanja uvjeta za pristup i korištenje
}

the open science movement and can be declared as conditio sine qua non.

The first initiative aimed at advocating for open access originated in Budapest in 2002 (Budapest Open Access Initiative, BOAI) and then it was defined that open access was considered as the free availability of scientific literature on the public network, allowing all users without financial, legal or technical obstruct to read, download, copy, distribute, print, search or link to the full texts of these articles, index or use them for any other lawful purpose, all while providing authors with control over the integrity of the work and the right to appropriate recognition and citation. Two strategies for achieving open access are proposed: Self-Archiving and publishing in Open-Access Journals (Budapest Open Access Initiative 2002).

Croatian Declaration on Open Access $(2012,2)$, relying on previous initiatives, ${ }^{1}$ defined open access as "free, ${ }^{2}$ costless and unhindered access to digital scientific information that enables reading, storage, distribution, search, retrieval, indexing and / or other lawful use."

As scientific papers published in journals have imposed as the most important channel for reporting on scientific achievements and knowledge, open access most often refers to free access to papers published in journals. When talking about open access to scientific information, the European Commission also refers mostly to journals, distinguishing two categories of this concept: peer-reviewed scientific publications (primarily scientific articles published in scientific journals) and research data that complement reporting on scientific research results in journals or act independently within the research environment through complete and structured research data sets (European Commission - Open Access 2020).

Open access can be achieved in different ways, and divisions are present according to the type of publication (journal, book, etc.), used technology (website, digital repository, etc.), rights of use, legality of the platform and / or available paper versions,

\footnotetext{
Budapest Open Access Initiative (2002), Berlin Declaration on Open Access (2003), Budapest Declarations on the Right to Access Information (2008), Declaration on Open Access (IFLA, 2011), Principles and Recommendations for Access to Research Data created in the framework of publicly funded research (OECD, 2007), Recommendations on Access to and Preservation of Scientific Information (2012), Council of the European Union Conclusion on Scientific Information in the Digital Age: Access, Dissemination and Preservation (2007)

2 Permanently free from any restrictions and conditions for access and use
} 
kih podataka (European Commission - Open Access 2020).

Otvoreni pristup može se ostvariti na različite načine, a prisutne su podjele s obzirom na vrstu publikacije (časopis, knjiga i dr.), korištenu tehnologiju (web stranica, digitalni repozitorij i dr.), prava korištenja, legalnost platforme i/ili dostupne verzije rada i sl. Najpopularnija raščlamba vrsta otvorenog pristupa razlikuje zlatni (članci objavljeni u otvoreno dostupnim časopisima) i zeleni put (autori samoarhiviraju rad u institucijski ili neki drugi repozitorij) otvorenog pristupa. Danas zlatni put uključuje sve poslovne modele časopisa u otvorenom pristu$\mathrm{pu}$, a najčešće podrazumijeva naplaćivanje objave rada u otvorenom pristupu (eng. Article Processing Charges ili APC), pri čemu autor ili ustanova plaćaju izdavaču. Mnogi časopisi u otvorenom pristu$\mathrm{pu}$, posebice oni manjih akademskih izdavača, ne naplaćuju autorima objavu rada jer se financiraju iz proračuna, a kako bi se ti časopisi razlikovali od onih komercijalno orijentiranih, uvodi se koncept "dijamantnog" ili "non-APC" otvorenog pristupa. Takav otvoreni pristup i smjer izdavaštva pridonosi očuvanju nepristrane znanosti (Barić et al. 2017, 3). Također, veliki broj komercijalnih časopisa pripada kategoriji tzv. hibridnih časopisa, koji samo dio sadržaja nude u otvorenom pristupu, uz plaćanje, dok su drugi sadržaji nedostupni, osim putem pretplata. Takvi časopisi ne smatraju se časopisima otvorenog pristupa. Postoji i podjela na libre otvoreni pristup (korisnici mogu slobodno čitati i smiju ponovo upotrebljavati rad) i gratis otvoreni pristup (korisnici mogu samo slobodno čitati rad), jer osim pristupa, u prvi plan stavlja korištenje rada (Suber 2008). Među vrstama otvorenog pristupa Piwowar navodi i odgođeni otvoreni pristup, otvoreni pristup uz pomoć akademskih društvenih mreža i crni otvoreni pristup (Piwowar et al. 2018). Kako odgođeni otvoreni pristup uključuje embargo, tj. vrijeme tijekom kojega je rad nedostupan, dostupnost na akademskim društvenim mrežama ovisi o mijenjajućem poslovnom modelu društvene mreže i legalnosti pohranjene verzije rada, a crni otvoreni pristup ilegalno "otvaranje" zatvorenih radova na piratskim stranicama.

Nedvojbeno je da na pokret otvorene znanosti i načine ostvarivanja otvorenog pristupa danas snažno utječu velike izdavačke kuće i njihovi profiti pa je to glavnim uzrokom zašto istraživači otvoreni pristup izjednačuju s visokim cijenama objave rada. Također, nametnuti modeli naplaćivanja produbljuju razlike između bogatih i siromašnijih znanstvenih zajednica. Radovi istraživača siromašnijih zemalja etc. The most popular analysis of open access types distinguishes between the golden (articles published in open access journals) and green (authors self-archive work in an institutional or other repository) open access. Today, the golden route includes all business models of open access journals, and most often involves charging for the article publishing in an open access (Article Processing Charges or $A P C$ ), whereby the author or institution are paying the publisher. Many open access journals, especially those of smaller academic publishers, do not charge authors for publishing their paper because they are funded from the budget, and to differentiate them from commercially oriented ones, the concept of "diamond" or "non-APC" open access is introduced. Such open approach and direction of publishing contributes to the preservation of impartial science (Barić et al. 2017, 3). Also, a large number of commercial journals belong to the category of so-called hybrid journals, which offer only part of the content in open access, for a fee, while other content is unavailable, except through subscriptions. Such journals are not considered as open access journals. There is also a division into libre open access (users can read freely and may reuse the paper) and gratis open access (users can only read the paper freely), because in addition to access, it puts the use of paper in the foreground (Suber 2008). Among the types of open access Piwowar also cites delayed open access, open access with the help of academic social networks, and black open access (Piwowar et al. 2018). As delayed open access includes an embargo, i.e. the time during which work is unavailable, availability on academic social networks depends on the changing business model of the social network and the legality of the stored version of paper, and black open access illegally "opens" closed papers on pirated sites.

There is no doubt that the open science movement and ways of achieving open access today are strongly influenced by large publishing houses and their profits, so this is the main reason why researchers equalize open access with high article publishing prices. Also, imposed charging models deepen the differences between richer and poorer scientific communities. The papers of researchers from poorer countries are often published in closed access because there are no secured means to pay for open access, which reduces their readability, citation and impact. This is corroborated by the research of Mirjam Curno and Stephanie Oeben (2018) according to which, in the period from 2015 to 2017 , open access journals received on average $7 \%$ more cita- 
nerijetko bivaju objavljeni u zatvorenom pristupu jer ne postoje osigurana sredstva za plaćanje otvorenog pristupa, čime se smanjuje njihova čitanost, citiranost $\mathrm{i}$ utjecaj. To potkrepljuje $\mathrm{i}$ istraživanje Mirjam Curino i Stephanie Oeben (2018) prema kojem su, u razdoblju od 2015. do 2017. godine, časopisi otvorenog pristupa u prosjeku dobili $7 \%$ više citata od časopisa u zatvorenom pristupu. Iz navedenih se razloga npr. hrvatski autori više okreću dijamantnim časopisima, tj. onima koji ne naplaćuju otvoreni pristup, samoarhiviranju svojih radova $u$ otvorene repozitorije i dijeljenju svojih radova putem popularnih akademskih društvenih mreža.

Samoarhiviranjem rada autor pohranjuje cjeloviti tekst svog djela u institucijski, tematski ili nacionalni repozitorij koji je u otvorenom pristupu. Samoarhivirati se mogu različite inačice znanstvenih radova, ovisno o politici samoarhiviranja izdavača i njihovim pravilima. Autori svoj rad mogu podijeliti i na nekim drugim platformama kao što su društvene akademske mreže (npr. Mendeley, Academia.edu, ResearchGate). Samoarhiviranje i dijeljenje rada od znanstvenika zahtijeva dodatan angažman te je potrebno donositi obaveze na institucijskoj i nacionalnoj razini i unaprijediti informacijsku infrastrukturu (Macan 2018, 76). Usprkos takvim izazovima, ovaj model ima brojne koristi jer na taj način rad postaje vidljiviji, pristupačniji, pretraživiji i korišteniji (Cerejo 2013), a time i citiraniji.

Cilj ovog istraživanja je utvrditi prakse objavljivanja, pohranjivanja i dijeljenja znanstvenih radova autora Sveučilišta u Rijeci te utvrditi razlike s obzirom na tri skupine znanstvenih područja i korištene načine ostvarivanja otvorenog pristupa.

\section{Materijali i metode}

Analizirani su znanstveni radovi objavljeni u časopisima koje su objavili znanstvenici iz područja biomedicine i zdravstva, prirodnih znanosti, društvenih znanosti i humanističkih znanosti Sveučilišta u Rijeci u razdoblju 2017.-2019. godine.

Kao temelj za analizu korištena je Hrvatska znanstvena bibliografija (CROSBI) ${ }^{3}$ zbog njene cjelovitosti i sveobuhvatnosti, te su izdvojeni svi izvorni znanstveni i pregledni radovi objavljeni u časopisima od 2017. do 2019. godine, čiji su bibliografski podaci uneseni u CROSBI do 21. veljače 2020. a pridruženi nekoj od sastavnica Sveučilišta u Rijeci $(\mathrm{N}=1431)$.

3 https://www.bib.irb.hr/ tions than journals with subscription. From these reasons, for example, Croatian authors turn more to diamond journals, i.e. those that do not charge for open access, self-archiving of their work in open repositories and sharing their work through popular academic social networks.

Authors can self-archive the full-text of their paper in an institutional, thematic or national repository. Different versions of scientific papers can be self-archived, depending on the publisher's self-archiving policy and their rules. Authors can also share their paper on some other platforms such as social academic networks (e.g. Mendeley, Academia.edu, ResearchGate). Self-archiving and paper sharing require additional engagement from scientists and it is necessary to make commitments at the institutional and national level and improving the information infrastructure (Macan 2018, 76). Despite such challenges, this model has numerous benefits because in this way the paper becomes more visible, accessible, searchable and used (Cerejo 2013), and thus more cited.

The aim of this research is to determine the practices of publishing, archiving and sharing scientific papers of the authors of the University of Rijeka, and to identify differences with regard to the three groups of scientific fields and the methods used to achieve open access.

\section{Materials and methods}

Scientific papers in journals published by scientists in the field of biomedicine and health, natural sciences, social sciences and humanities of the University of Rijeka in the period from 2017 to 2019 were analysed. The Croatian Scientific Bibliography (CROS$\mathrm{BI})^{3}$ was used as a basis for the analysis due to its completeness and comprehensiveness, and all original scientific and review papers published in journals from 2017 to 2019, whose bibliographic data were entered into CROSBI by February 21, 2020, were singled out and associated with one of the constituents of the University of Rijeka ( $N=1431)$.

\section{Sample}

Due to differences in the models of dissemination of scientific results, 4 scientific fields were analysed, in 3 groups: biomedicine and health, natural sciences and the fields of social sciences and humanities. ${ }^{4}$

\footnotetext{
https://www.bib.irb.hr/

4 According to Pravilnik o znanstvenim i umjetničkim područjima, poljima i granama (Consolidated text - "Narodne novine" No. 118/09, $82 / 12,32 / 13$, and $34 / 16$ - unofficial)
} 


\section{Uzorak}

Zbog razlika u obrascima diseminacije znanstvenih rezultata, analizirana su 4 znanstvena područja, u 3 skupine: biomedicina i zdravstvo, prirodne znanosti i područja društvenih znanosti i humanističkih znanosti. ${ }^{4}$ Iz područja biomedicine i zdravstva izdvojeni su radovi Fakulteta zdravstvenih studija $(\mathrm{N}=88)$ i Medicinskog fakulteta $(\mathrm{N}=528)$. Za prirodne znanosti izdvojeni su radovi Odjela za fiziku $(\mathrm{N}=92)$ i Odjela za matematiku ( $\mathrm{N}=51)$, za društvene znanosti i humanističke znanosti izdvojeni su radovi Ekonomskog fakulteta $(\mathrm{N}=94)$, Fakulteta za menadžment u turizmu i ugostiteljstvu $(\mathrm{N}=121)$, Filozofskog fakulteta $(\mathrm{N}=251)$, Odjela za informatiku $(\mathrm{N}=23)$, Pravnog fakulteta $(\mathrm{N}=150)$ i Učiteljskog fakulteta $(\mathrm{N}=33)$.

Za svaki od tri stratuma (znanstvena područja) određen je probabilistički slučajni sustavni uzorak radova koji se kasnije analizirao. Prema ukupnom broju jedinica populacije u svakom stratumu (biomedicina i zdravstvo $\mathrm{N}=616$, prirodne znanosti $\mathrm{N}=143$, društvene znanosti i humanističke znanosti $\mathrm{N}=672$ ) određena je potrebna veličina uzorka za svako područje $(n=70)$ i veličina intervala za svako područje $\mathrm{k}=\mathrm{N} / \mathrm{n}$ (biomedicina i zdravstvo $\mathrm{k}=8$, prirodne $\mathrm{zna}$ nosti $\mathrm{k}=2$, društvene $\mathrm{i}$ humanističke znanosti $\mathrm{k}=9$ ). Početna jedinica za uzorkovanje za svaki skup slučajno je odabrana između $1 \mathrm{i}$ k, te se nadalje odabirala svaka k-ta jedinica. Ukupan broj jedinica za analizu u uzorku iznosi n=210 (Tablica 1).
In the field of biomedicine and health, the papers of the Faculty of Health Studies $(\mathrm{N}=88)$ and the Faculty of Medicine ( $\mathrm{N}=528)$ were selected. For the natural sciences selected articles are from the Department of Physics ( $\mathrm{N}=92)$ and the Department of Mathematics $(\mathrm{N}=51)$, for the social sciences and humanities, selected articles are from the Faculty of Economics $(\mathrm{N}=94)$, the Faculty of Tourism and Hospitality Management $(\mathrm{N}=121)$, the Faculty of Philosophy $(\mathrm{N}=251)$, the Department of Informatics $(\mathrm{N}=23)$, the Faculty of Law $(\mathrm{N}=150)$ and the Faculty of Teacher Education $(\mathrm{N}=33)$.

For every of three strata (scientific fields) a probabilistic random systematic sample of papers was determined which was later analysed. According to the total number of population units in each stratum (biomedicine and health $\mathrm{N}=616$, natural sciences $\mathrm{N}=143$, social sciences and humanities $\mathrm{N}=672$ ) the required sample size was determined for each area $(n=70)$ and the size of the interval for each area $\mathrm{k}=\mathrm{N} / \mathrm{n}$ (biomedicine and health $\mathrm{k}=8$, natural sciences $k=2$, social sciences and humanities $k=9$ ). The initial sampling unit for each set was randomly selected between 1 and $\mathrm{k}$, and each $\mathrm{k}$ unit was further selected. The total number of units for analysis in the sample is $n=210$ (Table 1 ).

Tablica 1. Oblikovanje uzorka u istraživanju otvorenosti i dijeljenja znanstvenih radova na Sveučilištu u Rijeci Table 1. Sample design in the research of open access and sharing of scientific papers at the University of Rijeka

\begin{tabular}{|c|c|c|c|}
\hline $\begin{array}{l}\text { Područje znanosti } \\
\text { Scientific field }\end{array}$ & $\begin{array}{l}\text { Sastavnica Sveučilišta u Rijeci } \\
\text { Constituent of the University of Rijeka }\end{array}$ & $\begin{array}{l}\text { Radovi u CROSBI bazi } \\
\text { Papers in CROSBI } \\
\text { N (\%) }\end{array}$ & $\begin{array}{l}\text { Uzorak } \\
\text { Sample } \\
\text { N (\%) }\end{array}$ \\
\hline \multirow{3}{*}{$\begin{array}{l}\text { Biomedicina i zdravstvo } \\
\text { Biomedicine and Health }\end{array}$} & $\begin{array}{l}\text { Fakultet zdravstvenih studija } \\
\text { Faculty of Health Studies }\end{array}$ & $88(6,1)$ & $11(5,2)$ \\
\hline & $\begin{array}{l}\text { Medicinski fakultet u Rijeci } \\
\text { Faculty of Medicine }\end{array}$ & $528(36,9)$ & $59(28,1)$ \\
\hline & $\begin{array}{l}\text { Ukupno - Biomedicina i zdravstvo } \\
\text { Total - Biomedicine and health }\end{array}$ & $616(43,0)$ & $70(33,3)$ \\
\hline \multirow{3}{*}{$\begin{array}{l}\text { Prirodne znanosti } \\
\text { Natural Sciences }\end{array}$} & $\begin{array}{l}\text { Odjel za fiziku } \\
\text { Department of Physics }\end{array}$ & $92(6,4)$ & $45(21,4)$ \\
\hline & $\begin{array}{l}\text { Odjel za matematiku } \\
\text { Department of Mathematics }\end{array}$ & $51(3,6)$ & $25(11,9)$ \\
\hline & $\begin{array}{l}\text { Ukupno - Prirodne znanosti } \\
\text { Total - Natural Sciences }\end{array}$ & $143(10,0)$ & $70(33,3)$ \\
\hline
\end{tabular}

\footnotetext{
4 Prema Pravilniku o znanstvenim i umjetničkim područjima, poljima i granama (Pročišćeni tekst - "Narodne novine" broj 118/09, 82/12, $32 / 13$ i $34 / 16$ - neslužbeni)
} 


\begin{tabular}{|c|c|c|c|}
\hline \multirow{7}{*}{$\begin{array}{l}\text { Društvene znanosti i } \\
\text { humanističke znanosti } \\
\text { Social Sciences and Humanities }\end{array}$} & $\begin{array}{l}\text { Ekonomski fakultet } \\
\text { Faculty of Economics }\end{array}$ & $94(6,6)$ & $10(4,8)$ \\
\hline & $\begin{array}{l}\text { Fakultet za menadžment u turizmu i } \\
\text { ugostiteljstvu } \\
\text { Faculty of Tourism and Hospitality } \\
\text { Management }\end{array}$ & $121(8,5)$ & $13(6,2)$ \\
\hline & $\begin{array}{l}\text { Filozofski fakultet } \\
\text { Faculty of Philosophy }\end{array}$ & $251(17,5)$ & $23(11,0)$ \\
\hline & $\begin{array}{l}\text { Odjel za informatiku } \\
\text { Department of Informatics }\end{array}$ & $23(1,6)$ & $3(1,4)$ \\
\hline & $\begin{array}{l}\text { Pravni fakultet } \\
\text { Faculty of Law }\end{array}$ & $150(10,5)$ & $17(8,1)$ \\
\hline & $\begin{array}{l}\text { Učiteljski fakultet } \\
\text { Faculty of Teacher Education }\end{array}$ & $33(2,3)$ & $4(1,9)$ \\
\hline & $\begin{array}{l}\text { Ukupno - Društvene znanosti i humanističke } \\
\text { znanosti } \\
\text { Total - Social Sciences and Humanities }\end{array}$ & $672(47,0)$ & $70(33,3)$ \\
\hline $\begin{array}{l}\text { Sva područja } \\
\text { All fields }\end{array}$ & & $1431(100,0)$ & $210(100,0)$ \\
\hline
\end{tabular}

\section{Postupak}

Znanstveni radovi analizirani su s obzirom na pristup, tj. otvorenost, pohranjivanje $u$ repozitorije i dijeljenje na društvenoj mreži ResearchGate. Dana je procjena stupnja sklonosti dijeljenja znanstvenog rada.

\section{Procjena otvorenosti znanstvenih radova}

Putem Google Scholar tražilice, pretragom po naslovu, provjereno je za sve jedinice iz uzorka jesu li $\mathrm{u}$ otvorenom pristupu na digitalnoj platformi pripadajućeg časopisa.

U prvom dijelu istraživanja ispitana je distribucija radova s obzirom na SCImago Journal Rank (SJR) metrički pokazatelj i praksa objavljivanja radova u otvorenom pristupu na Sveučilištu u Rijeci, a s obzirom na ispitivana područja znanosti i definirano razdoblje (2017.-2019.). Kriteriji za definiranje otvorenosti u ovom dijelu istraživanja ograničeni su na već spomenuti tzv. zlatni put otvorenog pristupa. Razlikujemo znanstvene radove objavljene $\mathrm{u}$ otvorenom pristu$\mathrm{pu}$ (objava rada $\mathrm{u}$ časopisu u otvorenom pristupu ili objava rada u otvorenom pristupu uz APC) i znanstvene radove objavljene u zatvorenom pristupu.

\section{Pohranjivanje znanstvenih radova i dijeljenje na društvenim mrežama}

Drugi dio istraživanja bavi se pohranjivanjem radova u repozitorije (Repozitorij UNIRI - Dabar, ArXiv, Crosbi) i dijeljenjem na društvenim mrežama (ResearchGate).

Pretragom po naslovu provjerena je prisutnost cjelovitog teksta u otvorenom pristupu za svaku je-

\section{Procedure}

Scientific papers were analysed with regard to access, i.e. openness, archiving in repositories and sharing on the social network ResearchGate. An assessment of the degree of tendency to share scientific paper is given.

\section{Assessment of the openness of scientific papers}

Through the Google Scholar search engine, by searching by title, all units from the sample were checked for whether they are in open access on the digital platform of the corresponding journal.

The first part of the research the distribution of papers was examined according to the metric indicator SCImago Journal Rank (SJR) and the practice of paper open access publishing at the University of Rijeka, with regard to the examined fields of science and the defined period (2017-2019). The criteria for defining openness in this part of the research are limited to the already mentioned so-called the golden route of open access. We distinguish between scientific papers published in open access (paper publishing in an open access journal or paper publishing in open access with the APC) and scientific papers published in closed access.

\section{Archiving scientific papers and sharing on social media}

The second part of the research deals with paper archiving in repositories (Repository UNIRI - Dabar, ArXiv, CROSBI) and sharing on social networks (ResearchGate). With the title search the presence 
dinicu uzorka u 3 repozitorija koji omogućavaju pohranu cjelovitog teksta rada, a koje smo odredili kao predstavnike specifičnih vrsti digitalnih platformi: institucijskog repozitorija (Repozitorij UNIRI), pre-print repozitorija (ArXiv) i nacionalne znanstvene bibliografije (Crosbi). Provjereno je također je li rad u cijelosti podijeljen na društvenoj mreži ResearchGate.

\section{Stupanj sklonosti dijeljenja rada}

Određivanjem stupnja sklonosti autora da pohrane cjeloviti rad u neku od digitalnih platformi (ArXiv, Repozitorij UNIRI, Crosbi) ili ga podijele putem društvene mreže Research Gate može ih se raščlaniti na one koji pokazuju visoku sklonost (samoarhivirali su ili podijelili cjeloviti tekst na dvije ili više platformi), nisku sklonost (samoarhivirali su ili podijelili cjeloviti tekst na jednoj platformi) ili nalazimo na izostanak sklonosti (nisu samoarhivirali ili podijelili cjeloviti tekst rada niti na jednoj platformi).

Uz pomoć konstrukta stupnja sklonosti ispitano je postojanje razlika u sklonosti samoarhiviranju i dijeljenju radova s obzirom na područje znanosti kojem autori pripadaju.

Osim stupnja sklonosti autora da samoarhiviraju ili dijele cjeloviti tekst rada s obzirom na područje znanosti, u trećem dijelu istraživanja ispitan je i odnos između stupnja sklonosti autora da samoarhivira ili dijeli svoj rad i kvalitativnih metričkih pokazatelja rada (SJR).

\section{Procjena metričkog pokazatelja}

Za potrebe istraživanja odabran je metrički pokazatelj časopisa SCImago Journal Rank (SJR) koji predstavlja alternativu popularnom čimbeniku odjeka časopisa (Journal Impact Factor ili JIF), a izračunava se također temeljem broja objavljenih radova i prikupljenih citata. Jedna od prednosti JCR je javna i besplatna dostupnost podataka putem portala SCImago Journal \& Country Rank. ${ }^{5}$ SJR kao izvor podataka koristi bazu podataka Scopus izdavača Elsevier.

Časopisi su razvrstani u znanstvena područja, a s obzirom na SJR, razvrstani su u kvartile (Q). Kvartili su u rasponu od prvog (Q1) do četvrtog (Q4) i odnose se na smještaj određenog časopisa u njegovoj poddisciplini s obzirom na SJR, ako rangiramo SJR indekse od najvećeg prema najmanjem. Dakle, časopis u prvom kvartilu (Q1) ima SJR u prvih 25\% časopisa za barem jednu od njegovih klasificiranih poddisciplina. of full text in open access was checked for each sample unit in 3 repositories that allow archiving of full text of the paper, which we identified as representatives of specific types of digital platforms: institutional repository (UNIRI Repository), preprint server (ArXiv) and national scientific bibliographies (CROSBI). It was also checked whether the paper was fully shared on the social network ResearchGate.

\section{Degree of tendency to paper sharing}

By determining the degree of tendency of the author to store the entire paper in one of the digital platforms (ArXiv, UNIRI Repository, CROSBI) or share it through the social network Research Gate, they can be divided into those that show high inclination (self-archived or split the whole text into two or more platforms), low inclination (self-archived or shared the full text on one platform) or we find a lack of inclination (they did not self-archive or share the full text of the paper on any platform).

With the help of the degree construct of tendency, the existence of differences in the tendency of self-archiving and paper sharing with regard to the science field to which the authors belong was examined.

In addition to the degree of tendency of authors to self-archive or share the full text of the paper considering the field of science, the third part of the study examined the relationship between the degree of tendency of authors to self-archive or share their paper and qualitative metric indicators (SJR).

\section{Estimation of metric indicator}

For the purposes of the research, the metric indicator SCImago Journal Rank (SJR) was selected, which is an alternative to the popular Journal Impact Factor (JIF), and is also calculated based on the number of published papers and collected citations. One of the advantages of JCR is the public and free availability of data through the SCImago Journal \& Country Rank portal ${ }^{5}$. SJR as a data resource uses the Scopus database published by Elsevier.

Journals are classified into scientific fields, considering SJR, they are classified into quartiles (Q). Quartiles are in the range from the first (Q1) to the fourth (Q4) and refer to the placement of a particular journal in its subdiscipline considering SJR, if we rank SJR indexes from highest to lowest. Thus, a journal in the first quartile (Q1) has a SJR in the top 25\% of journals for at least one of its classified subdisciplines. 


\section{Etički aspekti istraživanja}

Istraživanje je odobrilo Povjerenstvo za etička pitanja Medicinskog fakulteta Sveučilišta u Rijeci kao dio projekta "Poznavanje, stavovi i korištenje alata otvorene znanosti u biomedicini (uniri-biomed-18-99 1234)" Sveučilišta u Rijeci.

\section{Statističke metode}

Za prikaz rezultata i statističku obradu podataka korišteni su računalni programi otvorenog koda OpenOffice Calc 4.1.7 i JASP 0.12.2.

Korišten je $\chi^{2}$-test za kategorijske varijable.

Povezanost je iskazana neparametrijskim koeficijentom korelacije Spearman.

Svi rezultati interpretirani su na razini statističke značajnosti $\mathrm{P}<0,05$.

\section{Rezultati i rasprava}

\section{Distribucija radova s obzirom na SJR metrički pokazatelj}

Distribucija radova Sveučilišta u Rijeci (2017.2019.) s obzirom na SJR metrički pokazatelj časopisa u kojima su objavljeni radovi $(\mathrm{P}<0,001)$ pokazuje da znanstvenici iz područja biomedicine $\mathrm{i}$ zdravstva i prirodnih znanosti značajno više objavljuju u časopisima u prva dva kvartila, koje uvjetno možemo nazvati prestižnijim časopisima: čak je $78,6 \%(\mathrm{~N}=55)$ prirodoznanstvenih i $70 \%(\mathrm{~N}=49)$ biomedicinskih radova objavljeno u Q1 i Q2 časopisima. U društvenim znanostima i humanističkim znanostima prevladavaju radovi objavljeni u Q3 i Q4 časopisima i onima koji nisu indeksirani u bazi Scopus pa niti nemaju dodijeljen kvartil $[\mathrm{N}=57$ (81,4\%)] (Slika 1). SCImago Journal Rank donekle normalizira razlike u zakonitostima citiranja između različitih znanstvenih područja što u određenoj mjeri dopušta usporedbe među znanstvenim područjima. Scopus je sveobuhvatnija baza podataka od Web of Science citatnih indeksa koji se koriste za izračunavanje JIF te uključuje više hrvatskih časopisa. Za razliku od JIF koji koristi dvogodišnji citatni prozor, SJR koristi trogodišnji citatni prozor (u izračun uključuje citate koje su u tekućoj godini prikupili radovi objavljeni u prethodne tri godine), što je primjerenije ne toliko dinamičnim znanstvenim područjima kao što je npr. biomedicina. Također, SJR ne vrednuje svaki citat jednako, već veću težinu daje citatima iz prestižnijih časopisa (prema SJR). Prednost mu je i što uključuje samo 33\% samocitata, čime je donekle uklonjen utjecaj prekomjernog samocitiranja časopisa (Macan i Petrak 2015, 35-37).

\section{Ethical aspects of research}

The research was approved by the Ethics Committee of the University of Rijeka Medical Faculty as part of the project Knowledge, attitudes and use of open science tools in biomedicine (uniri-biomed-18-99).

\section{Statistical methods}

For the review of results and statistical data processing open-source computer programs OpenOffice Calc 4.1.7 and JASP 0.12.2 were used.

The $\chi^{2}$-test was used for categorical variables.

The correlation is calculated with nonparametric Spearman correlation coefficient.

All results were interpreted at the level of statistical significance $\mathrm{P}<0.05$.

\section{Results and discussion}

\section{Distribution of papers considering SJR metric indicator}

Distribution of papers of the University of Rijeka (2017-2019), considering journal SJR metric indicator in which the papers were published $(\mathrm{P}<0.001)$, shows that scientists in the fields of Biomedicine and Health and Natural sciences publish significantly more in journals in the top two quartiles, which can be conditionally called more prestigious journals: even $78.6 \%(\mathrm{~N}=55)$ Natural science and 70\% $(\mathrm{N}=49)$ Biomedical papers are published in $\mathrm{Q} 1$ and Q2 journals. In the fields of Social sciences and Humanities papers are published in lower quartiles - Q3 and Q4 journals prevail as well as those which are not indexed in the Scopus database and do not even have a assigned quartile [N=57 (81.4\%)] (Figure 1). SCImago Journal Rank somewhat normalizes the differences in citation validity between different scientific fields which to some extent allows comparisons between scientific fields. Scopus is a more comprehensive database than Web of Science citation indexes which are used to calculate JIF and includes more Croatian journals. Unlike JIF that uses a twoyear citation window, a SJR uses a three-year citation window (the calculation includes citations collected in the current year by papers published in the previous three years), which is more appropriate for less dynamic scientific fields such as biomedicine. Also, SJR does not value every citation equally, but gives more significance to citations from more prestigious journals (according to SJR). Its advantage is that it includes only $33 \%$ of self-citations, which somewhat removes the impact of excessive self-citation of the journal (Macan, Petrak 2015, 35-37). 


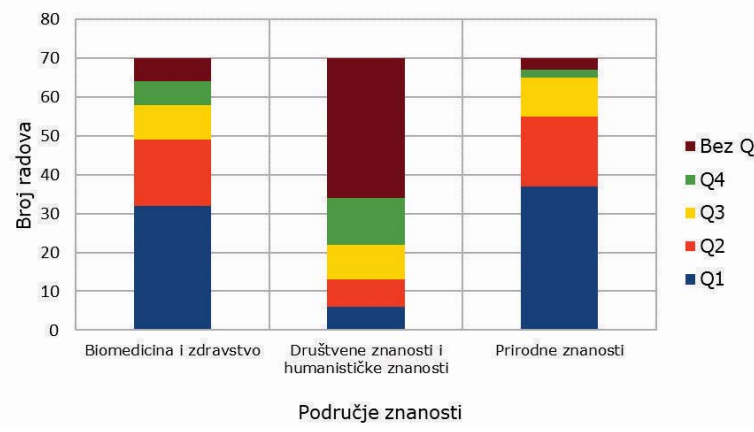

Slika 1. Distribucija radova Sveučilišta u Rijeci s obzirom na područje znanosti i SJR kvartile $(\mathrm{N}=210, \mathrm{P}<0,001)$

Trend objave unutar društvenih znanosti i humanističkih znanosti u ovom istraživanju prisutan je i u svjetskoj produkciji radova iz društvenih znanosti i humanističkih znanosti (Liu i Li 2018, 117; Ennas i Di Guardo 2015, 86) i može se objasniti njihovom prirodom u kojima su istraživanja nerijetko lokalno relevantna, objavljena u hrvatskim časopisima, na hrvatskom jeziku. Smatramo da su navike objavljivanja hrvatskih znanstvenika povezane s kriterijima za napredovanja u znanstvenim i znanstveno-nastavnim zvanjima, koji u svim područjima osim humanističkih znanosti snažno potiču ili pak zahtijevaju od znanstvenika objavljivanje u prestižnim časopisima ${ }^{6}$

\section{Objavljivanje otvoreno dostupnih znanstvenih radova u znanstvenim časopisima}

Udio znanstvenih radova $\mathrm{u}$ otvorenom pristupu $[\mathrm{N}=107(51 \%)]$ približno je jednak udjelu radova u zatvorenom pristupu $[\mathrm{N}=103(49 \%)](\mathrm{P}=0,836)$.

U objavljivanju radova u otvorenom pristupu prednjače znanstvenici iz društvenih znanosti i humanističkih znanosti $[N=46(65,7 \%)]$, dok značajno više radova u zatvorenom pristupu objavljuju znanstvenici iz prirodnih znanosti $[\mathrm{N}=48(68,6 \%)]$ (Slika 2; $\mathrm{P}<0,001)$.

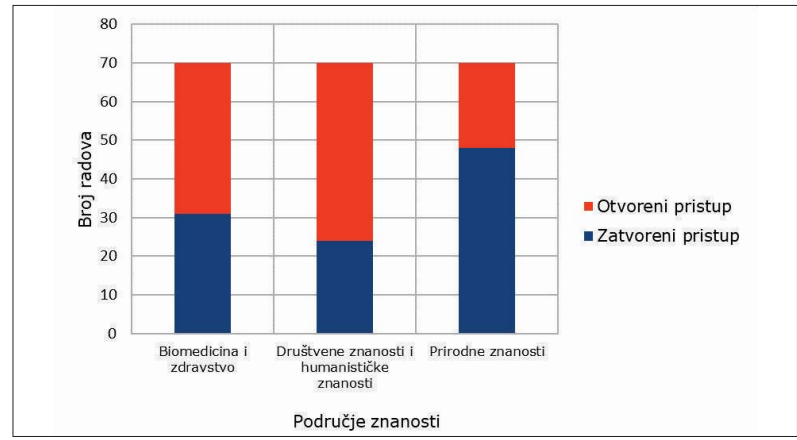

Slika 2. Otvorenost radova Sveučilišta u Rijeci s obzirom na područje $(\mathrm{N}=210, \mathrm{P}<0,001)$

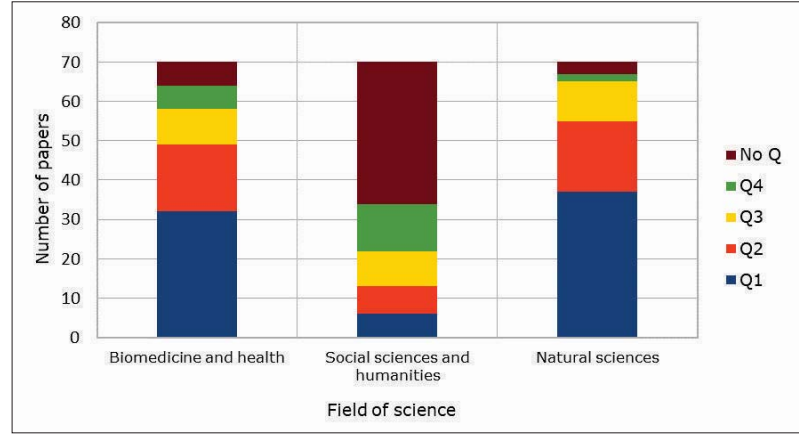

Figure 1. Distribution of papers of the University of Rijeka considering scientific field and SJR quartile $(\mathrm{N}=210, \mathrm{P}<0.001)$

The trend of publishing within the Social sciences and Humanities in this research is also present in the world production of papers (Liu and Li 2018, 117; Ennas and Di Guardo 2015, 86) and can be explained by their nature in which research is often locally relevant, published in Croatian journals, in the Croatian language. We believe that the publishing habits of Croatian scientists are related to the criteria for advancement in scientific and scientific-teaching professions, which in all areas except the humanities, strongly encourage or require scientists to publish in prestigious journals. ${ }^{6}$

\section{Publishing open access articles in scientific journals}

The share of scientific papers in open access [ $\mathrm{N}=107$ $(51 \%)]$ is approximately equal to the share of papers in closed access $[\mathrm{N}=103(49 \%)](\mathrm{P}=0.836)$. Scientists from Social sciences and Humanities are in the lead in publishing open access papers $[\mathrm{N}=46$ $(65.7 \%)]$, while significantly more papers in closed access are published by natural science scientists $[\mathrm{N}=48(68.6 \%)]$ (Figure 2; $\mathrm{P}<0.001)$.

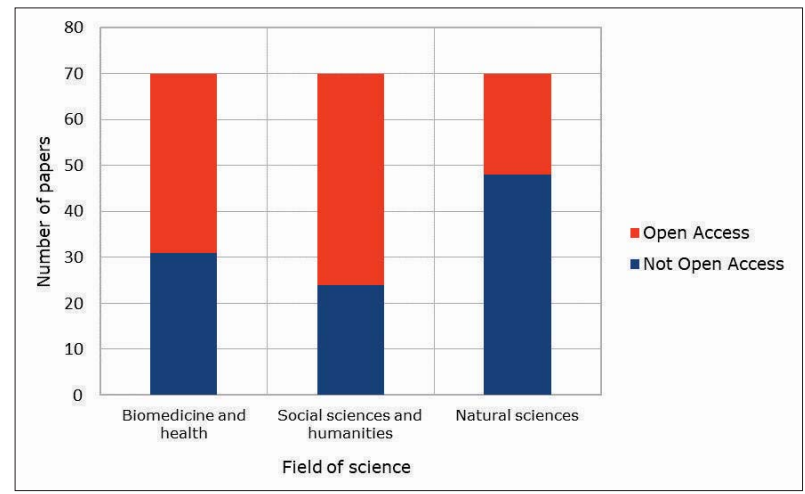

Figure 2. Openness of the papers of the University of Rijeka considering scientific field $(\mathrm{N}=210, \mathrm{P}<0.001)$

\footnotetext{
6 According to "Pravilnik o uvjetima za izbor u znanstvena zvanja" (Narodne Novine, No. 28/17), https://narodne-novine.nn.hr/clanci/ sluzbeni/2017_03_28_652.html.
}

\footnotetext{
Prema "Pravilnik o uvjetima za izbor u znanstvena zvanja" (Narodne Novine, broj 28/17), https://narodne-novine.nn.hr/clanci/sluzbeni/2017_03_28_652.html.
} 
Unutar cijelog skupa, kod znanstvenih radova objavljenih u Q1 i Q2 časopisima više je zatvorenih znanstvenih radova [Q1 - N=49 (65,3\%); Q2 - $\mathrm{N}=29$ (69\%)], dok su autori znanstvenih radova objavljenih u Q3 i Q4 časopisima skloniji otvorenom pristupu [Q3 - N=19 (67,9\%), Q4 - N=17 $(85 \%)$ ] (Slika 3; $\mathrm{P}<0,001)$.

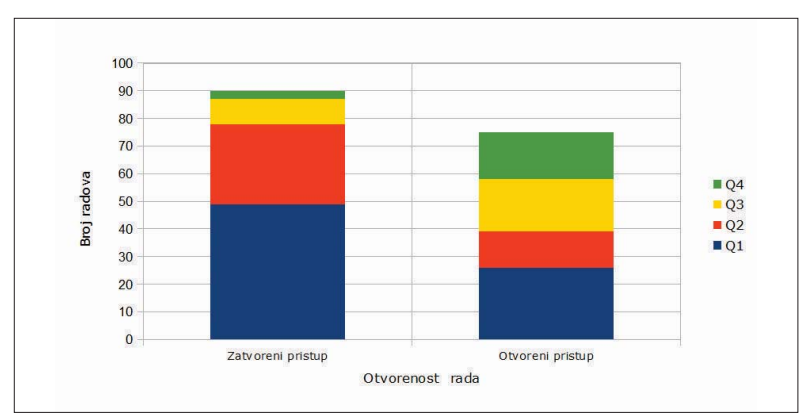

Slika 3. Otvorenost radova Sveučilišta u Rijeci s obzirom na SJR kvartil časopisa u kojima su objavljeni $(N=210 ; P<0,001)$

\section{Praksa dijeljenja i samoarhiviranja radova}

Analizom prakse dijeljenja i samoarhiviranja znanstvenika Sveučilišta u Rijeci u odabranim platformama uočava se da je s najvećim brojem radova korištena platforma ResearchGate $(\mathrm{N}=77)$, zatim slijede ArXiv ( $\mathrm{N}=32)$, Repozitorij UNIRI (N=15) i Crosbi ( $\mathrm{N}=9$ ).

\section{Crosbi}

Hrvatska znanstvena bibliografija (Crosbi) omogućuje autorima da uz bibliografski zapis mogu pohraniti (samoarhivirati) i cjeloviti tekst rada. U ovom istraživanju uočeno je da je 9 radova arhivirano u Hrvatskoj nacionalnoj bibliografiji, te je uz bibliografske podatke o tim radovima dostupan i pristup cjelovitom tekstu rada. Svi su radovi iz društvenog i humanističkog područja znanosti. Smatramo da je razlog malog broja pohrane taj što autori ne moraju pohranjivati cjeloviti tekst već samo bibliografske podatke.

\section{Repozitorij UNIRI}

Repozitorij UNIRI ${ }^{7}$ jest institucijski repozitorij Sveučilišta u Rijeci i dio je Digitalnog akademskog arhiva i repozitorija (Dabar). U njega su uključeni i u njemu aktivni svi fakulteti i odjeli obuhvaćeni ovim istraživanjem, no infrastruktura repozitorija se zasada uglavnom koristi za arhiviranje završnih i diplomskih radova (77,3\%), a tek se $6,6 \%$ zapisa odnosi na znanstvene radove zaposlenika Sveučilišta u Rijeci. Unutar uzorka ove analize pronađeno je tek 15 radova arhiviranih u repozitorij, i to mahom iz područja biomedicine i zdravstva $(\mathrm{N}=14)$. Uzrok

https://www.unirepository.svkri.uniri.hr/
Within the whole set, there are more closed scientific papers published in Q1 and Q2 journals [Q1 - N=49 (65.3\%); Q2 - N=29 (69\%)], while the authors of scientific papers published in Q3 and Q4 journals are more inclined to open access [Q3 - N=19 (67.9\%), $\mathrm{Q} 4-\mathrm{N}=17$ (85\%)] (Figure 3; $\mathrm{P}<0.001$ ).

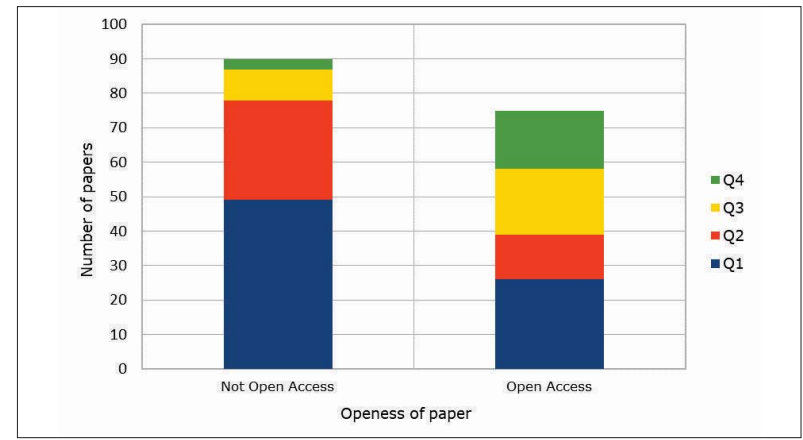

Figure 3. Openness of the papers of the University of Rijeka considering SJR quartile of the journals in which they were published $(\mathrm{N}=210 ; \mathrm{P}<0.001)$

\section{The practice of sharing and papers self-archiving}

Analysis of the practice of sharing and self-archiving of the University of Rijeka scientists in selected platforms shows that the ResearchGate platform was used with the largest number of papers $(\mathrm{N}=77)$, followed by ArXiv ( $\mathrm{N}=32)$, UNIRI Repository $(\mathrm{N}=15)$ and CROSBI $(\mathrm{N}=9)$.

\section{CROSBI}

The Croatian Scientific Bibliography (CROSBI) enables authors to self-archive the full text of a paper in addition to the bibliographic record. In this research, it was noticed that 9 papers were archived in the Croatian National Bibliography, and in addition to bibliographic data on these papers, access to the full text of the paper is available. All papers are from the Social sciences and Humanities. We believe that the reason for the small number of storage is that the authors do not have to store full text but only bibliographic data.

\section{UNIRI Repository}

UNIRI Repository ${ }^{7}$ is the institutional repository of the University of Rijeka and is part of the Digital Academic Archives and Repositories (Dabar). It includes all active faculties and departments covered by this research, but the repository infrastructure is currently mainly used for archiving final and graduate theses $(77.3 \%$ ), and only $6.6 \%$ of records relate to scientific papers of employees of the University of Rijeka. Within the sample of this analysis, only 15 papers archived in the repository were

https://www.unirepository.svkri.uniri.hr/ 
malom broju samoarhiviranih znanstvenih radova može se pronaći i u relativno nedavnom uspostavljanju platforme. Prvi objekt u otvorenom pristupu pohranjen je u repozitorij u rujnu 2015. godine. Od tada broj svih vrsta pohranjenih objekata kontinuirano raste i za očekivati je da će se povećati i broj samoarhiviranih znanstvenih radova (Sveučilište u Rijeci, 2020).

\section{ArXiv}

Otvoreni repozitorij ArXiv, ${ }^{8}$ kao kanal distribucije uglavnom nerecenziranih tzv. pre-print (a ponekad i recenziranih) inačica radova, u ovom istraživanju očekivano koriste gotovo isključivo znanstvenici prirodnih znanosti, što je u skladu s tematskim okvirima tog repozitorija i ustaljenom praksom prirodoznanstvenih autora. Gledajući cijeli skup u ArXiv-u su samoarhivirana 32 rada, no gotovo svi znanstveni radovi [96,9\% $(\mathrm{N}=31)]$ su iz područja prirodnih znanosti, a samo $3,1 \%(\mathrm{~N}=1)$ iz društvenih znanosti, točnije područja informatike.

Iako su znanstvenici iz prirodnih znanosti skloniji objavljivati radove $\mathrm{u}$ zatvorenom $[\mathrm{N}=48(68,6 \%)]$ nego $\mathrm{u}$ otvorenom pristupu $[\mathrm{N}=22(31,4 \%)]$, njih gotovo polovica se odlučuje pohraniti nerecenziranu pre-print ili recenziranu inačicu rada u ArXiv $[\mathrm{N}=31(44,3 \%)]$. Na to se u podjednakoj mjeri odlučuju i autori koji su objavili rad u časopisu u otvorenom pristupu $[\mathrm{N}=11(50 \%)]$, kao i oni koji su objavili rad u časopisu u zatvorenom pristupu $[\mathrm{N}=20(41,6 \%)](\mathrm{P}=0,695)$ (Slika 4.).

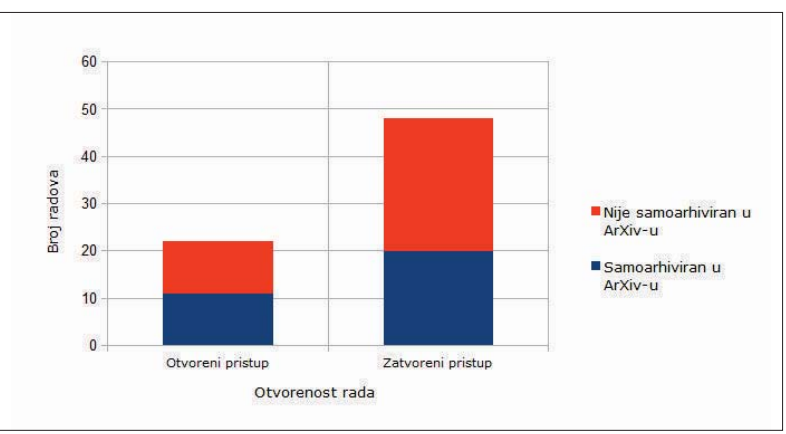

Slika 4. Broj radova prisutnih u ArXiv-u s obzirom na objavljenost rada kao otvoreno dostupnog u znanstvenom časopisu u prirodnim znanostima $(\mathrm{N}=70 ; \mathrm{P}=0,695)$

Jedina vidljiva razlika vezana je uz inačicu rada koju pohranjuju pa tako oni autori koji su objavili rad u časopisu u zatvorenom pristupu, a odlučili su ga pohraniti u ArXiv, češće izabiru samoarhiviranje nerecenzirane pre-print inačice rada (pre-print $\mathrm{N}=12$, recenzirani $\operatorname{rad} \mathrm{N}=8$ ). $\mathrm{S}$ druge strane, oni autori koji su objavili rad u znanstvenom časopisu

\footnotetext{
8 https://arxiv.org/
}

found, mostly in the field of biomedicine and health $(\mathrm{N}=14)$. The cause of the small number of self-archived scientific papers can also be found in the relatively recent establishment of the platform. The first object in open access was stored in a repository in September 2015. Since then, the number of all types of stored objects has been continuously growing and it is expected that the number of self-archived scientific papers will increase (University of Rijeka, 2020).

\section{ArXiv}

Open access archive ArXiv, ${ }^{8}$ as a distribution channel for mostly unreviewed so-called pre-print (and sometimes peer-reviewed) versions of papers, in this research, is anticipatedly used, almost exclusively by scientists of the natural sciences, which is in line with the thematic framework of this repository and the established practice of the authors of natural sciences. Looking at the whole set in ArXiv, 32 papers were self-archived, but almost all scientific papers $[96.9 \%(\mathrm{~N}=31)]$ are from the field of Natural sciences, and only $3.1 \%(\mathrm{~N}=1)$ from the field of Social sciences, more precisely field of informatics. Although scientists in the field of Natural science are more likely to publish papers in closed access $[\mathrm{N}=48(68.6 \%)]$ than in open access $[\mathrm{N}=22$ (31.4\%)], almost half of them choose to store unreviewed pre-print or peer-reviewed version of the paper in ArXiv [N=31 (44.3\%)]. Authors who have published a paper in an open access journal $[\mathrm{N}=11(50 \%)]$, as well as those who have published a paper in a closed access journal [N=20 (41.6\%)] $(\mathrm{P}=0.695)$, equally decide to do so (Figure 4).

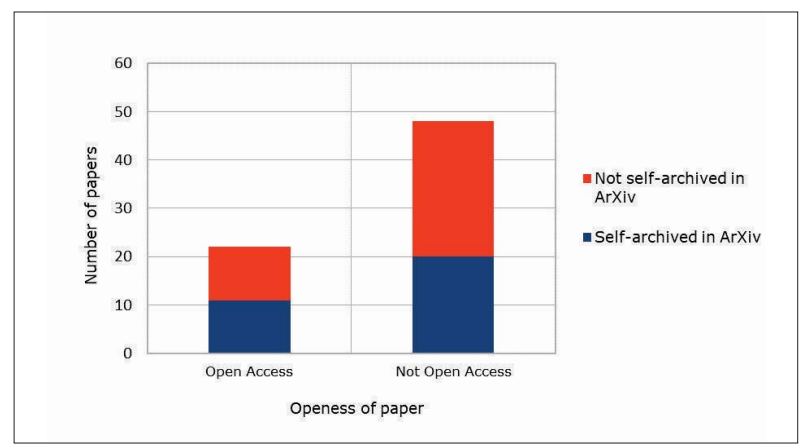

Figure 4. Number of papers present in ArXiv considering the publishing of the paper as openly available in a natural sciences scientific journal $(N=70 ; P=0.695)$

The only visible difference is related to the version of the paper they store, so those authors who published the paper in a closed access journal, and decided to store it in ArXiv, more often choose to

\footnotetext{
8 https://arxiv.org/
} 
u otvorenom pristupu, a odlučili su ga pohraniti u ArXiv, češće izabiru arhiviranje recenzirane inačice rada (pre-print $\mathrm{N}=3$, recenzirani $\operatorname{rad} \mathrm{N}=8$ ).

\section{ResearchGate}

Čak 77 radova iz cijelog skupa prisutno je u ResearchGate- $u^{9}$ sa samoarhiviranim i javno dostupnim cjelovitim tekstom rada. U sličnim omjerima $\mathrm{i}$ bez značajnih razlika $(\mathrm{P}=0,366)$ prisutni su samoarhivirani radovi u sva tri područja: u biomedicini i zdravstvu $\quad[\mathrm{N}=25 \quad(35,7 \%)]$, prirodnim znanostima $[\mathrm{N}=30(42,7 \%)]$ i društvenim znanostima i humanističkim znanostima $[\mathrm{N}=22$ $(31,4 \%)]$ (Slika 5.).

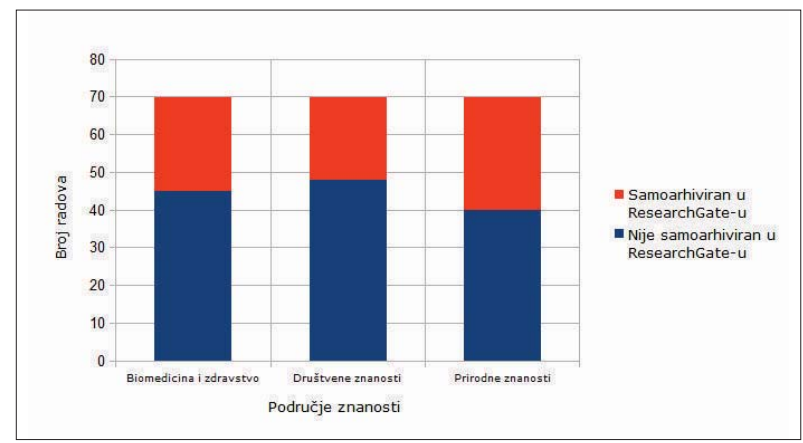

Slika 5. Prisutnost samoarhiviranih radova na ResearchGate akademskoj mreži s obzirom na otvorenost radova ( $N=210$; $P=0,366)$

Ako promotrimo samo radove koji su u zatvorenom pristupu (nisu objavljeni u časopisima u otvorenom pristupu ili u otvorenom pristupu uz naknadu za objavljivanje) uočava se da su znanstvenici iz prirodnih znanosti najskloniji takve radove samoarhivirati, i time otvoriti, na ResearhGate društvenoj mreži [N=15 (31,3\%)]. U nešto manjem omjeru su to učinili znanstvenici iz društvenih znanosti i humanističkih znanosti $[\mathrm{N}=5(20,8 \%)]$ i područja biomedicine i zdravstva $[\mathrm{N}=4(12,9 \%)]$.

Iako nije dijelom koncepta otvorenog pristupa, zanimljivo je spomenuti da je na akademskoj društvenoj mreži ResearchGate moguće i samo pohraniti bibliografske podatke o radu uz koje se nalazi polje za zahtjev cjelovitog teksta autoru rada. Takav zahtjev pristiže na e-mail adresu autora zapisa i on potom odlučuje hoće li e-mailom podijeliti svoj rad s korisnikom. Takav način sudjelovanja na ResearchGate-u, samo s bibliografskim podacima uz mogućnost zahtjeva cjelovitog teksta, prilično je ustaljen među autorima obuhvaćenim ovim istraživanjem. Promatrajući sva područja zajedno čak $43,8 \%(\mathrm{~N}=92)$ radova iz ispitivanja sudjeluje na self-archive the unreviewed pre-print version of the paper (pre-print $\mathrm{N}=12$, peer-reviewed work $\mathrm{N}=8$ ). On the other hand, those authors who published the paper in an open access scientific journal, and decided to store it in ArXiv, more often choose to archive a peer-reviewed version of the paper (preprint $\mathrm{N}=3$, peer-reviewed paper, $\mathrm{N}=8$ ).

\section{ResearchGate}

As many as 77 papers from the entire set are present in ResearchGate ${ }^{9}$ with a self-archived and publicly available full text of the paper. Self-archived papers are present in similar proportions and without significant differences $(\mathrm{P}=0.366)$ in all three groups: in Biomedicine and Health $[\mathrm{N}=25$ (35.7\%)], Natural sciences $[\mathrm{N}=30(42.7 \%)]$ and Social sciences and Humanities [ $\mathrm{N}=22$ (31.4\%)] (Figure 5).

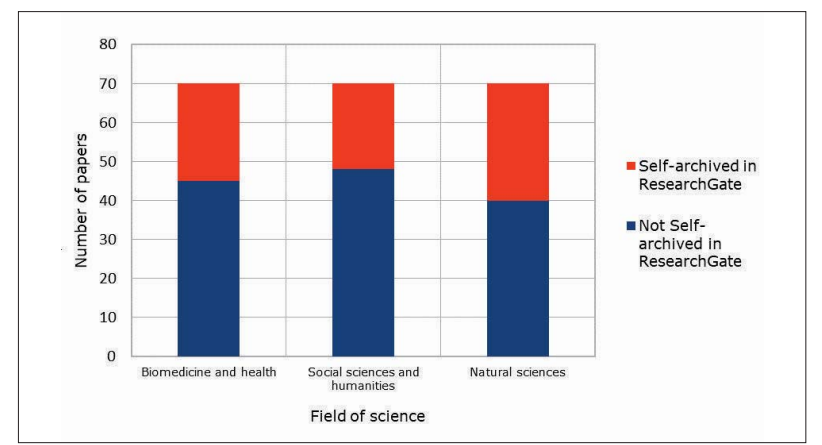

Figure 5. Presence of self-archived papers in the ResearchGate academic network considering the openness of the papers $(\mathrm{N}=210 ; \mathrm{P}=0.366)$

If we look only at papers that are in closed access (not published in open access journals or in open access with a publication fee), it is noticed that scientists from the field of Natural sciences are most inclined to self-archive such papers, and thus open them, on the ResearhGate social network $[\mathrm{N}=15$ $(31.3 \%)]$. To a lesser extent, this was done by scientists from the field of Social sciences and Humanities $[\mathrm{N}=5(20.8 \%)]$ and the fields of Biomedicine and Health $[\mathrm{N}=4(12.9 \%)]$.

Although it is not part of the concept of open access, it is interesting to mention that on the ResearchGate it is possible to only store bibliographic data of the paper (next to which there is a field for requesting the full text from the author). Such request arrives to the e-mail address of the author of the record and then author decides whether to share their work with the user by e-mail. Such way of participating in ResearchGate, with only bibliographic data with the possibility of requesting a full text, is 
ResearchGate mreži na ovakav način, a među njima s najvećim udjelom prednjače radovi iz područja biomedicine i zdravstva $[\mathrm{N}=39(42,4 \%)]$.

Motivacija autora da podijele rad na akademskoj društvenoj mreži povezana je sa željom za povećanje vidljivosti rada. U skladu s tzv. OACA (engl. Open Access Citation Advantage) hipotezom koja tvrdi da jednostavnost pristupa radu, tj. otvorenost rada, može povećati vidljivost $i$, posljedično, potencirati učestalost citata koje rad dobiva, dijeljenjem radova na akademskim društvenim mrežama autori imaju bolju šansu za vidljivost i citiranje (Cintra i sur. 2018, 119; Ramezani-Pakpour-Langeroudi i sur. 2018).

Motivacija autora da prisustvuju samo bibliografskim podacima rada bez dijeljenja cjelovitog teksta rada može se vezati uz svijest autora o autorskopravnim ograničenjima koja nameću politike nekih izdavača.

\section{Analiza sklonosti samoarhiviranju znanstvenih radova}

Nešto više od polovice radova nije samoarhivirano [N=112 (53,3\%)], $63(30 \%)$ znanstvena rada podijeljena su na jednoj platformi, odnosno imaju nizak stupanj sklonosti, a tek $35(16,7 \%)$ je podijeljeno na dvije platforme $(\mathrm{P}<0,001)$ i ima visok stupanj sklonosti samoarhiviranju znanstvenih radova. Nisu pronađeni znanstveni radovi podijeljeni na više od dvije platforme.

Od svih ispitanih područja znanosti, analiziramo li radove s visokim stupnjem sklonosti samoarhiviranju i dijeljenju, prednjače autori iz područja prirodnih znanosti $[\mathrm{N}=21(60 \%)]$ (Slika 6).

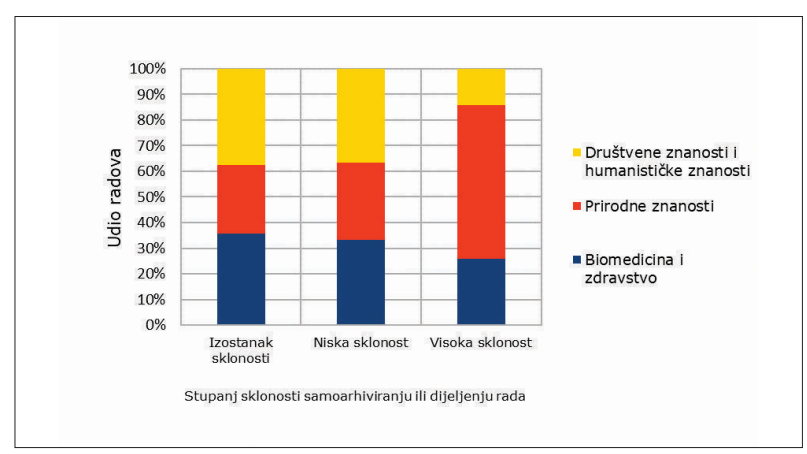

Slika 6. Stupanj sklonosti autora da samoarhiviraju ili dijele cjeloviti tekst rada s obzirom na područje znanosti ( $N=210$; $\mathrm{P}=0,006$ )

Ako ustvrdimo da autorova intervencija samoarhiviranja ili dijeljenja rada koji je inače u zatvorenom pristupu ima veliki značaj za otvaranje tog znanstvenog rada globalnoj znanstvenoj zajednici, potrebno je promotriti samo radove $u$ zatvorenom pristupu i quite common among the authors included in this research. Looking at all groups together, as many as $43.8 \%(\mathrm{~N}=92)$ of the papers from the study participate in the ResearchGate network in this way, and among them papers from the field of Biomedicine and Health $[\mathrm{N}=39$ (42.4\%)] are in the lead.

The motivation of the authors to share the work on the academic social network is related to the desire to increase the visibility of the paper. In accordance with the so-called OACA (Open Access Citation Advantage) hypothesis claiming that simplicity of access to paper, i.e. openness of paper can increase visibility and, consequently, emphasize the frequency of citations that the paper receives, by sharing papers on academic social networks, authors have a better chance of visibility and citation (Cintra et al. 2018, 119; Ramezani-Pakpour-Langeroudi et al. 2018).

The motivation of authors to appear with only bibliographic data of the paper without sharing the full text of the paper may be related to the author's awareness of copyright restrictions imposed by the policies of some publishers.

\section{Analysis of the scientific papers self-archiving tendency}

Slightly more than half of the papers are not self-archived [ $\mathrm{N}=112(53.3 \%)], 63(30 \%)$ scientific papers are shared on one platform or have a low degree of tendency, and only $35(16.7 \%)$ are shared on two platforms $(\mathrm{P}<0.001)$ and has a high degree of tendency to self-archive scientific papers. No scientific papers were found shared on more than two platforms.

Of all the examined fields of science, if we analyse papers with a high degree of tendency for self-archiving and sharing, the leading authors are from the field of Natural sciences [N=21 (60\%)] (Figure 6).

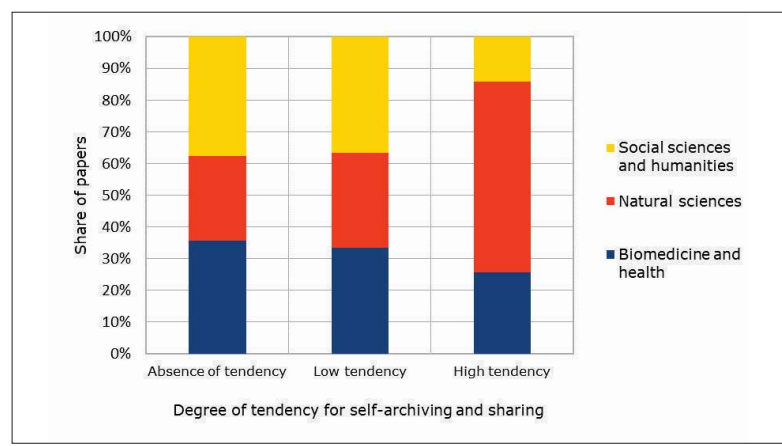

Figure 6. The degree of authors tendency to self-archive or share the full text of a paper considering the field of science $(N=210 ; P=0.006)$

The author's intervention of self-archiving or sharing a paper that is otherwise in closed access for opening of that scientific paper to the global sci- 
kakav je obrazac dijeljenja i samoarhiviranja samo u toj skupini. Od sva tri ispitana područja znanosti, visoki stupanj sklonosti samoarhiviranju i dijeljenju znanstvenih radova koji su objavljeni u zatvorenom pristupu u najvećem su omjeru [N=13 $(92,6 \%)]$ pokazali također autori iz područja prirodnih znanosti (Slika 7, $\mathrm{P}=0,004$ ).

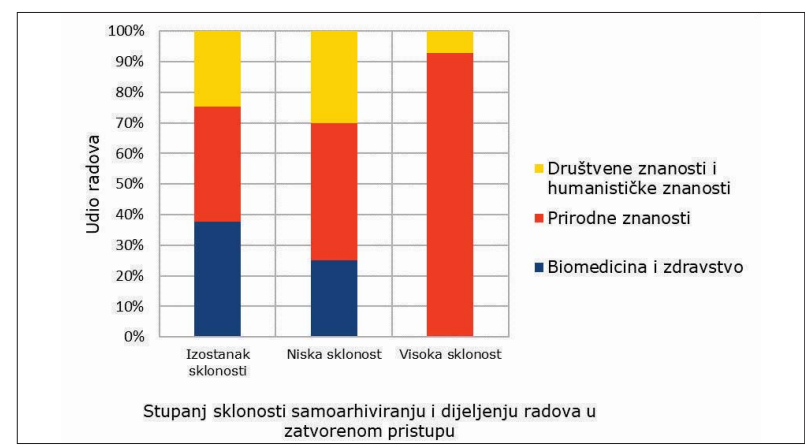

Slika 7. Stupanj sklonosti autora da samoarhiviraju ili dijele cjeloviti tekst rada koji je objavljen u zatvorenom pristupu s obzirom na područje znanosti $(N=103 ; P=0,004)$

Nije nađena značajna povezanost stupnja sklonosti autora da samoarhivira ili javno podijeli svoj rad i metričkog pokazatelja SJR časopisa u kojem je rad objavljen ( $\mathrm{P}=0,116)$. Isto je vidljivo na Slici 8 . koja ukazuje na podjednaku razinu sklonosti autora da samoarhiviraju ili podijele svoj rad (bilo u niskom ili visokom stupnju) i izostanaka te sklonosti $(\mathrm{P}=0,102)$.

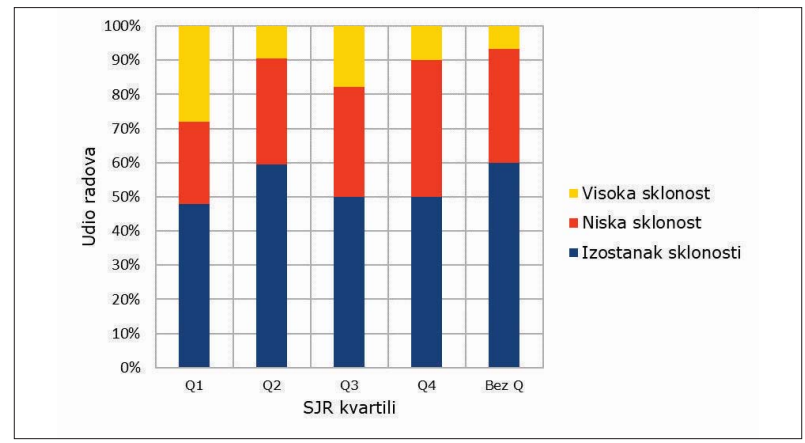

Slika 8. Stupanj sklonosti autora da samoarhiviraju ili dijele cjeloviti tekst rada (bez obzira na to je li objavljen u otvorenom ili zatvorenom pristupu) s obzirom na metrički pokazatelj SJR časopisa u kojem je rad objavljen ( $N=210$; $\mathrm{P}=0,102$ )

Ovo istraživanje ima ograničenje, rađeno je na uzorku radova, ne na cjelokupnoj publicistici djelatnika Sveučilišta u Rijeci niti u svim područjima. Moguće je da neka područja imaju drugačije navike ili da bi rezultati na cjelokupnom uzorku bili neznatno drugačiji. Također, nismo sigurni da je popis bibliografskih podataka u Crosbiju potpun, no jedini je važeći u RH. entific community is of great importance. Thus, it is necessary to consider only closed access papers and what is the pattern of sharing and self-archiving only in that group. Of all three examined fields of science, the high degree of tendency for self-archiving and sharing of scientific papers published in a closed access was also shown to the greatest extent $[\mathrm{N}=13(92.6 \%)]$ by authors from the field of Natural sciences (Figure 7, $\mathrm{P}=0.004$ ).

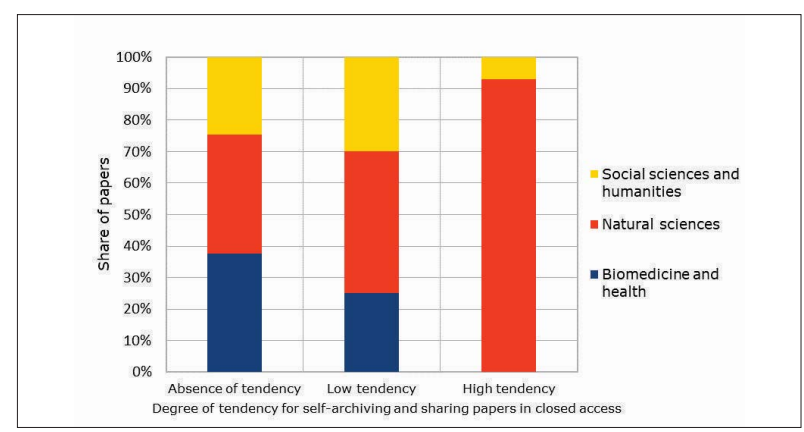

Figure 7. The degree of authors tendency to self-archive or share the full text of a paper published in a closed access considering the field of science $(\mathrm{N}=103 ; \mathrm{P}=0.004)$

No significant correlation was found between the degree of tendency of the author to self-archive or publicly share their paper and the metric indicator of the journal's SJR in which the paper was published $(\mathrm{P}=0.116)$. The same is evident in Figure 8, which indicates an equal level of tendency of authors to self-archive or share their paper (either in a low or high degree) and the absence of that propensity $(\mathrm{P}=0.102)$.

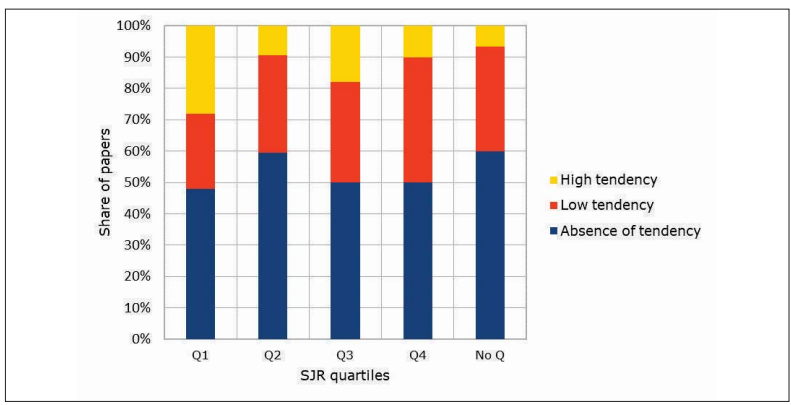

Figure 8. Degree of authors tendency to self-archive or share the full text of a paper (whether published in open or closed access) considering the metric indicator of the journal's SJR in which the paper was published $(\mathrm{N}=210 ; \mathrm{P}=0.102)$

This research has a limitation, it was done on a sample of papers, not on the entire publishing activity of the employees of the University of Rijeka nor in all the fields. It is possible that some fields have different habits or that the results on the whole sample would be slightly different. Also, we are not sure that the list of bibliographic data in Crosby is complete, but it is the only one valid in the Republic of Croatia. 


\section{Zaključak}

U razdoblju od 2017. do 2019. godine znanstvenici Sveučilišta u Rijeci iz područja biomedicine i zdravstva i prirodnih znanosti najviše objavljuju svoje radove u časopisima svrstanim u SJR kvartile Q1 i Q2, $\mathrm{i}$ to podjednako u otvorenom i zatvorenom pristupu. Autori iz područja društvenih i humanističkih znanosti više naginju objavljivanju u Q3 i Q4 časopisima, te onim časopisima koji nisu indeksirani i nemaju dodijeljen SCImago Journal Rank indikator, što je u skladu s obrascima objavljivanja i specifičnostima društvenih znanosti i humanističkih znanosti.

Znanstvenici Sveučilišta u Rijeci u podjednakom omjeru objavljuju svoje radove u otvorenom i zatvorenom pristupu u znanstvenim časopisima. No, postoje razlike između područja znanosti. Pa tako $\mathrm{u}$ objavljivanju radova u otvorenom pristupu prednjače znanstvenici iz društvenih znanosti i humanističkih znanosti, dok značajno više radova u zatvorenom pristupu objavljuju znanstvenici iz prirodnih znanosti.

Ako se u tom kontekstu promotri i pripadnost radova cijelog skupa određenom SJR kvartilu časopisa, vidljivo je da je više radova u Q1 i Q2 časopisima koji su u zatvorenom pristupu, a oni u Q3 i Q4 časopisima su češće $u$ otvorenom pristupu.

Analiza dijeljenja i samoarhiviranja radova u otvorene platforme (ResearchGate, ArXiv, Repozitorij UNIRI, Crosbi) pokazala je da nešto više od polovice radova nije samoarhivirano i da znanstvenici Sveučilišta u Rijeci najviše dijele znanstvene radove na društvenoj akademskoj mreži ResearchGate, i to sva tri područja podjednako. Slijedi platforma ArXiv, kojom se gotovo isključivo koriste autori iz prirodnih znanosti, i to u veliko obujmu - gotovo svaki drugi autor iz tog područja. Mali je udio radova koji se samoarhiviraju u Crosbi platformi, i to su isključivo oni iz društvenih znanosti i humanističkih znanosti. U najmanjoj mjeri se koristi Repozitorij UNIRI - institucijski repozitorij Sveučilišta u Rijeci koji je dio Digitalnog akademskog arhiva i repozitorija (Dabar). Institucijski repozitorij Sveučilišta u Rijeci jest infrastrukturno i praktično platforma s najviše potencijala za osiguravanje tzv. zelenog puta otvorenog pristupa kroz arhiviranje i dijeljenje znanstvenih radova djelatnika Sveučilišta. Osim toga, Sveučilište u Rijeci je jedna od rijetkih ustanova u Hrvatskoj koja službeno podupire i daje podršku otvorenoj znanosti kroz Deklaraciju Sveučilišta u Rijeci "Europska otvorena znanost"10 od 22. siječnja 2019. godine. Očito još

\footnotetext{
${ }^{10} \mathrm{https}$ ://kampus.svkri.uniri.hr/images/Nacrt_Deklaracije_ Sveučilišta_u_Rijeci_-_Otvorena_europska_znanost.pdf
}

\section{Conclusion}

In the period from 2017 to 2019, scientists from the University of Rijeka in the fields of Biomedicine and Health and Natural sciences mostly publish their papers in journals classified in SJR quartiles Q1 and Q2, both in open and closed access. Authors in the fields of Social sciences and Humanities are more inclined to publish in Q3 and Q4 journals, and those journals that are not indexed and do not have an SCImago Journal Rank indicator, which is in line with publishing forms and specifics of Social Sciences and Humanities. Scientists of the University of Rijeka publish their papers in open and closed access in scientific journals in equal ratio. But there are differences between the fields of science. Thus, scientists from the Social sciences and Humanities are in the lead in publishing open access papers, while significantly more papers in the closed access are published by scientists from the field of Natural sciences. If in this context the affiliation of the papers of the whole set to a certain SJR quartile of journals is observed, it can be seen that more papers in Q1 and Q2 journals are in closed access, and those in Q3 and Q4 journals are more often in open access. The analysis of sharing and self-archiving papers in open platforms (ResearchGate, ArXiv, Repository UNIRI, CROS$\mathrm{BI}$ ) showed that slightly more than half of the papers are not self-archived and that scientists from the University of Rijeka mostly share scientific papers on the ResearchGate social academic network, for all three fields equally. This is followed by the ArXiv platform, which is used almost exclusively by authors from the field of natural sciences, and on a large scale - almost every other author from that field. There is a small share of papers that are self-archived in the CROSBI platform, and these are exclusively those from the Social sciences and Humanities.

The UNIRI Repository is the least used - the institutional repository of the University of Rijeka, which is part of the Digital Academic Archive and Repository (Dabar). The Institutional Repository of the University of Rijeka is an infrastructural and practical platform with the most potential for securing the so-called a green route of open access through archiving and sharing the scientific papers of University employees.

In addition, the University of Rijeka is one of the few institutions in Croatia that gives and officially supports open science through the Declaration of the University of Rijeka - European Open Science ${ }^{10}$ of 22 January 2019. Obviously, there is still a period to

\footnotetext{
${ }^{10}$ https://kampus.svkri.uniri.hr/images/Nacrt_Deklaracije Sveučilišta_u_Rijeci_-_Otvorena_europska_znanost.pdf
} 
predstoji razdoblje da se obrasci i navike djelatnika Sveučilišta, koje takva podrška zagovara, usvoje u većem opsegu.

Kako bismo bolje razjasnili i shvatili sklonost autora da samoarhivira ili podijeli svoj rad na otvorenoj platformi, uveden je konstrukt stupanj sklonosti. Prateći pokazatelj stupnja sklonosti, u sklonosti samoarhiviranju i dijeljenju rada prednjače znanstvenici iz prirodnih znanosti, čak i ako promotrimo isključivo samoarhiviranje i dijeljenje radova koji su objavljeni u zatvorenom pristupu. Nije uočena povezanost između SJR kvartila časopisa u kojem je objavljen rad i sklonosti autora da samoarhivira ili podijeli svoj rad na nekoj otvorenoj platformi.

\section{Literatura / Bibliography}

- Ayris, Paul, and Tiberius Ignat. 2018. "Defining the role of libraries in the Open Science landscape: a reflection on current European practice" Open Information Science 2: 1-22. DOI: https://doi. org/10.1515/opis-2018-0001

- Barić, Hrvoje, Ksenija Baždarić, Anton Glasnović, and Srećko Gajović. 2017. "Why scholarly publishing might be a bubble" Croatian Medical Journal 58: 1-3. DOI: https://doi. org/10.3325/cmj.2017.58.1

- Budapest Open Access Initiative. 2002. Last modification: March 25, 2020. https://www. budapestopenaccessinitiative.org/read

- Cerejo, Clarinda. 2013 "How to make your paper more accessible through self-archiving" Editage insights Nov 04, DOI: https://doi.org/10.34193/ EI-A-6374

- Cintra,PauloRoberto,AriadneChloeFurnival, and Douglas Henrique Milanez. 2018. "The impact of open access citation and social media on leading top Information Science journals" Investigación bibliotecológica 32: 117-132. DOI: https://doi. org/10.22201/iibi.24488321xe.2018.77.57874

- Curno, Mirjam, and Stephanie Oeben. 2018. "Scientific Excellence at Scale: Open Access journals have a clear citation advantage over subscription journals" Frontiers Announcements, posted on July 11. https://blog.frontiersin. org/2018/07/11/scientific-excellence-at-scaleopen-access-journals-have-a-clear-citationadvantage-over-subscription-journals/

- Deklaracija Sveučilišta u Rijeci. 2019. "Europska otvorena znanost" Last modification: April 25, 2020. https://kampus.svkri.uniri.hr/images/ Nacrt_Deklaracije_Sveučilišta_u_Rijeci_-_ Otvorena_europska_znanost.pdf come before the forms and habits of the University employees, advocated by such support, are adopted to a greater extent.

In order to clarify better and understand the author's propensity to self-archive or share their paper on an open platform, a construct degree of tendency was introduced. Following the indicator of the degree of tendency, the tendency for self-archiving and paper sharing is led by scientists in the field of Natural sciences, even if we look exclusively at self-archiving and sharing of papers published in a closed access. No connection was observed between the SJR quartile of the journal in which the paper was published and the author's tendency to self-archive or share their paper on an open platform.

- Dizdar, Srebren. 2019. "Za i protiv otvorenog pristupa akademskim djelima u kontekstu savremenog istraživačko-izdavačkog procesa" Bosniaca 24: 26-38. DOI: https://doi.org/10.37083/ bosn.2019.24.26

- Ennas, Gianfranco, and Maria Chiara Di Guardo. 2015. "Features of top-rated gold open access journals: An analysis of the scopus database" Journal of Informetrics 9 (1): 79-89. DOI: https://doi.org/10.1016/j.joi.2014.11.007

- European Commisson. 2020. "Open Access" Last modification: March 15, 2020. https://ec.europa.eu/ research/openscience/index.cfm?pg=openaccess

- European Commisson. 2019. "Open Science Factsheet" Last modification: March 15, 2020. https://ec.europa.eu/info/sites/info/files/research_and_innovation/knowledge_publications_tools_and_data/documents/ec_rtd_factsheet-openscience_2019.pdf.

- Hrvatska deklaracija o otvorenom pristupu. 2012. Last modification: March 15, 2020. http://www. uaos.unios.hr/artos/Hrvatska_deklaracija_o_ otvorenom_pristupu.pdf

- Liu, Weishu, and Yanchao Li. 2018. "Open access publications in sciences and social sciences: A comparative analysis" Learned Publishing 31 (2): 107-119. DOI: https://doi.org/10.1002/ leap. 1114

- Macan, Bojan. 2018. "Osiguravanje otvorenog pristupa znanstvenim publikacijama: tko, što i kako?" U Otvorenost u znanosti $i$ visokom obrazovanju, edited by Ivana Hebrang Grgić, 59-79. Zagreb: Školska knjiga.

- Macan, Bojan, and Jelka Petrak. 2015. "Bibliometrijski pokazatelji za procjenu kvalitete znanstvenih časopisa" U Hrvatski znanstveni časopisi: 
iskustva, gledišta, mogućnosti, edited by Ivana Hebrang Grgić, 37-53. Zagreb: Školska knjiga.

- Piwowar, H., J. Priem, V. Larivière, J. P. Alperin, L. Matthias, B. Norlander, A. Farley, J. West, and S. Haustein. 2018. "The state of OA: a large-scale analysis of the prevalence and impact of Open Access articles" PeerJ 6: e4375. DOI: https://doi. org/10.7717/peerj.4375

- Pontika, Nancy, Petr Knoth, Matteo Cancellieri, and Samuel Pearce. 2015. "Fostering open science to research using a taxonomy and an eLearning portal" $i-K N O W$ '15: Proceedings of the 15th International Conference on Knowledge Technologies and Data-driven Business, 1-8. DOI: https://doi.org/10.1145/2809563.2809571

- Ramezani-Pakpour-Langeroudi, Fatemeh, Maryam Okhovati, and Ali Talebian. 2018. "Do highly cited clinicians get more citations when being present at social networking sites?" Journal of Education and Health Promotion 7: 18. DOI: https://doi.org/10.4103/jehp.jehp_69_17
- SCImago, (n.d.). SJR. 2020. "SCImago Journal \& Country Rank [Portal]" Last modification: March 15, 2020. http://www.scimagojr.com

- Suber, Peter. 2008. "Gratis and libre open access" SPARC Open Access Newsletter 124. http://legacy.earlham.edu/ peters/fos/ newsletter/08-02-08.htm

- Sveučilište u Rijeci. 2020. Repozitorij

Sveučilišta u Rijeci: statistika pohrane objekata [skup podataka]. Last modification: May 13, 2020. https://www.unirepository.svkri.uniri.hr/ stats/objects

- Tennant, Jonathan et al. 2020. "A Tale of Two 'opens': Intersections Between Free and Open Source Software and Open Scholarship" SocArXiv. March 6. DOI: https://doi. org/10.31235/osf.io/2kxq8

- Watson, Mick. 2016. "When Will 'Open Science' Become Simply 'Science'?” Genome Biology 16: 101. DOI: https://doi.org/10.1186/s13059-0150669-2 